\title{
A Critical Review of Social Protection Policies, Programs and Their Effectiveness in Nepal
}

Dilli Raj Khanal, PhD ${ }^{1}$

\begin{abstract}
The objective of the paper is to review the existing literature on social security and social protection program in Nepal carried out by Government of Nepal and offered suggestion for the betterment of the program in the line of equality, financial sustainability and economic growth. The paper is prepared based on the desk review of the various scientific articles and report published by the institutions and individual authors. In total 64 papers have been reviewed published during ten years period ranges from 2006 to 2015.

Based on the critical review the paper conclude that Dalits, endangered community, school girls, child and people living in the remote areas such as Karnali have been benefitted from numerous social security related programs. The doubling of social assistance is enhancing social protection of those who are in such nets. However, social security programs lack effectiveness compared to increased budget, scattered programs implemented through different agencies in many instances in an adhoc basis without effective coordinated implementation mechanism has made the outcomes less beneficial and effective from the standpoint of intended beneficiaries. One of the serious challenges in the areas of social security is that still all workers working in the informal economy consisting of more than 96 per cent of the total labor force are outside the purview of social security program. The new Integrated Social Security act has also not covered the workers in the informal sector. Similarly, it encompasses through many ambiguities and overlaps. A big chunk of entitled population is deprived of getting the benefits of such programs. More worryingly, out of them, most deprived are disabled.
\end{abstract}

Key Words: Social Security, Social Protection, Social Assistance, Deprived and Disabled,

1 Dr. Khanal, a former member of the National Planning Commission and Parliament, teaches advance macroeconomics to M. Phil. students at the Central Department of Economics, TU. Email: drkhanal10@gmail.com 


\section{Introduction}

\subsection{General Background}

Social protection is defined as a set of public policies and programs that seek to assure a minimum level of security to the people and support in meeting their needs (ILO, 2010). Social protection is increasingly recognized as a critical component of development discourse as it helps to protect poor people by promoting inclusive growth and reducing inequality simultaneously (EC 2010; Alderman and Yemtsov, 2012). As such, it contributes to reduce inequalities across key population groups by empowering, for instance, women and girls, youth, older persons and persons with disabilities (Townsend, 2009 and ESCAP, 2015).Thus, social protection, if well-designed, not only addresses vulnerabilities, poverty and other related problems but also contributes to equitable, inclusive and sustainable growth and development. This is why social security and protection have received prominence place in the Sustainable Development Goals (SDGs) ${ }^{2}$.

Noticeably, Nepal has been in the forefront in introducing social protection program and hence social protection has emerged as one of the important public policy tools. For the first time, the CPN (UML) government initiated universal social pension scheme for the elderly, single women and disabled people in the mid 1990s (Khanal, 2014a). Such schemes have been expanded and scaled up after the political change of 2006 in which post-conflict development and reconstruction programs also received some priorities (Holmes and Uphadya, 2009; Koehler, 2011). The scheme was further extended to endangered races and differently able persons in 2008 through the budget of 2008/09. The budget additionally reduced the eligibility age threshold for Dalits and citizens of the Karnali Zone. In 2016/17, the allowance was doubled at Rs. 2000 per month for the elderly and others who are entitled to get such a pension. In parallel, various grants, scholarships, social insurances and other forms of social assistance programs are also under implementation. Apart from such schemes, social security facility is enjoyed by the retired employees (having pension - all civil services and corporations). Importantly, Nepal's constitution gives highest priority to the social security and protection program which is conceived as one of the pillars of the socialist oriented economy.

As a consequence of early initiation and subsequent expansion, Nepal is now ahead compared to many other South Asian countries in providing one or other form of social protection to the citizens. Despite this, the life of the people is still very difficult owing to limited employment opportunities and limited access to quality basic services and physical infrastructure (Holmes and Uphadya, 2009). Poor growth performance, lack of adequate productive employment, prolonged political instability and social exclusion

2 There is also an argument that social protection should include life security of both individuals and households. Such an argument has received momentum along with increased crime, intimidation and murder in the society amidst inability of the state to protect its citizens.

$2 \sim$ Nepalese Journal of Insurance and Social Security 
in the form of gender, caste, ethnicity, language and geography are often cited to be the major sources of vulnerabilities and socio-economic insecurity in Nepal (Koehler, 2011). Because of such numerous reasons, poverty intensity among the most vulnerable population is still very high and also human development remains one of the lowest in South Asian region (UNDP, 2014). Nepal is also prone to natural calamities like flooding, landslides and fire every year leading to aggravation of vulnerabilities of the people. In such a situation, role of social protection to minimize exclusion and poverty intensity led vulnerabilities and narrow down the gap between haves and have-nots becomes very critical and important. This indicates that not only coverage but also effectiveness of social protection program is very crucial in the countries like Nepal.

In this brief paper below, at first, a brief introduction of ongoing policies and programs linked to social protection is made. This is followed by a critical review on the effectiveness of such policies and programs, methodology and major conclusions and suggestions are presented in the last section.

\subsection{Overview of Social Protection Policies and Programs}

Social protection policies and programs can be grouped into two broad categories: social insurance and social assistance.

\subsubsection{Social Insurance}

Social insurance comprises of programs that cover the risks associated with unemployment, sickness, maternity, disability, industrial injury and old age (ADB, 2008). It thus includes old-age insurance, health insurance, unemployment insurance and programs for workers with disabilities (ADB, 2011). More specifically, four social insurance programs are in practice in Nepal: (i) Retirement benefits such as pension, gratuities, allowances and medical facilities, (ii) Employees' Provident Fund, (iii) Citizen Investment Trust, and (iv) Social Security Fund.

In terms of government expenditure, social insurance constitutes the largest category of social protection in Nepal at more than 60.0 per cent of annual social security expenditure in FY 2017/18. The formal social insurance programs are targeted at particular employment groups- usually employees in the public sector.

One of the recent programs under social insurance is social security fund. The social protection coverage broadly consistent with social protection floor was first proposed in the budget of 2066/67. For that purpose, one per cent tax in the first slab of taxable income of the salaried people was loosely proposed in the budget. This was followed by the formulation of a Social Security Fund Management and Operation Regulation in 2067. This led to the establishment of Social Security Fund. The main objective of the Fund is to keep record of all the collected contributions into a computerized system and implement various social insurance schemes. Through the budget of 2068/69 it was stated that the 
collected social security fund will be used to provide insurances for workplace accident, maternity health and health insurance etc. A Board of Trustees formed consisting of 11 members representing the three main partners Government, Employers and Trade Unions is entrusted to make decisions on social protection related schemes. The records as of 14 June 2015 show that altogether 1461 employers (government, non-government and private sector) with a total of 1,049,446 individual workers are registered in the Social Security Fund (ILO, 2015). However, the most disappointing aspect is that hardly any payment has been made by the Fund to the intended beneficiaries. Consequently, billions of Rupees is accumulated in the Fund account. Another feature of such a Fund is that the primary contributors are the government agencies and only a small proportion has been contributed by the formal private sector employers. One of the positive developments in this area is that a comprehensive act has already been enacted in which both social insurance and social assistance programs are included in it. More broadly, the act attempts to include both social security and protection programs that are kept in the constitution.

\subsubsection{Social Assistance}

Assistance for the elderly, health assistance, child protection, disaster relief assistance and other forms of assistance targeting the poor and vulnerable people come under social assistance program. These are generally targeted towards benefiting entire needy people in one way or the other (Upreti, et al. 2012). In Nepal social assistance programs include senior citizen's allowance, single women allowance, disability allowance, endangered indigenous people's allowance, child grant, scholarships, food for education project, aama or mother program and transportation subsidies on essential foods. Since few years, apart from free health care program, program of distributing essential medicine has also been introduced and extended gradually. After adhoc and approached based financial support practices for long, more system based support for the treatment of costly and dangerous diseases has also been initiated and expanded over the years. Dangerous diseases like cancer, heart and a few others come to such a funding category. Unlike the social insurance program, social assistance programs are non-contributory and hence are directly covered from government's annual budget. People getting pensions and other benefits from the government and formal corporate sector are prevented from receiving these social assistance facilities. Similarly, if an individual falls in different targeted categories, she or he has to choose only one category which provides the higher allowance.

Apart from these, a number of social protection initiatives were taken after 2006 for the conflict victims of 1996 to 2006. The Ministry of Peace and Reconstruction is responsible for such programs and interventions aimed at building social cohesion, restoring peace and reducing vulnerability amongst those affected by the armed conflict. Major conflict related social protection interventions included scholarship for children whose $4 \sim$ Nepalese Journal of Insurance and Social Security 
parents are deceased or disappeared, onetime cash grant of NRs. 25000 to widows and families of missing persons, bearing of treatment costs for injuries incurred in conflict, onetime cash grant of NRs. 200000 to persons disabled during conflict, skills training for victims' families and quota seats for victims' families in foreign employment (Upreti, 2012). In addition to these, there are also meso forms of social protection such as poverty alleviation fund, micro-insurance such as crop and livestock insurance, employment schemes, micro finance and various subsidies (Koehler, 2014). Now health insurance has also been introduced and extended. Recent budgets have announced additional assistance programs to the conflict victims apart from extending more targeted social protection programs to the most deprived castes and socio-economic groups.

\section{Review of Literature}

\subsection{Critical Review on the Effectiveness of Policies and Programs of Nepal}

As a result of continuous efforts since the mid1990s, Nepal has been able to make steady progresses in the areas of social protection in terms of both coverage and outreach. The latest Social Protection index (SPI) ${ }^{3}$ of ADB shows that Nepal scored 0.068 compared to 0.051 by India, 0.047 by Pakistan, 0.043 by Bangladesh, 0.036 by Bhutan and 0.121 by Sri Lanka (ADB, 2013) ${ }^{4}$. The same study points out that despite being a low-income country Nepal spent about 2.1 per cent of GDP on social protection covering 4 million people (15 percent of the population). The $14^{\text {th }}$ Plan (2016/17-2018/19) points out that social protection allowances (excluding social insurance) are benefiting nearly 22 lacks and 65 thousand people. Similarly, a study covering country's social protection expenditures targeted to all potential beneficiaries reveals that about 4.8 percent of per capita poverty line expenditures is spent in social protection" (Upreti, et. al, 2012, p39).

However, despite such a progress at the aggregate level amidst relatively a moderate share of annual budget towards social security compared to many other developing countries, program lacks effective results due to scattered implementation through different agencies (MoF, 2014 and ILO, 2015). Diverse social security protection programs launched in many instances in an adhoc basis with poor and less effective coordinated implementation mechanism have made the outcomes less beneficial from the standpoint of intended beneficiaries. This is corroborated by many studies devoted to assess various components of the social protection programs.

3 The overall SPI is a weighted sum of the SPIs for social insurance, social assistance, and labour market programs (ADB, 2013).

4 When the country's social protection expenditures are averaged over all potential beneficiaries, it allocates 4.8 percent of per capita poverty line expenditures to social protection" (Upreti, et. al, 2012, p39). 
Examining the benefit level, Koehler (2014) points that the benefit is in the range of Rs. 200- 500 per month which is far from enough to meet the persisting poverty gap. Many studies point out that not only cash transfers but also both child grants and scholarship schemes are inadequate (DoE, 2010 and ERDCN, 2011). A survey by the NPC(2012) substantiates this. The survey finds that almost 80 per cent respondents feel the allowance insufficient to meet their personal and household expenditure and further indicates that poor, women and Dalits are in need of more allowances than others. KC et al.(2014) also derive the similar conclusions. Studies also point that implementation constraints such as low institutional capacity and funding bottlenecks are obstructing regular and predictable deliveries of cash transfers leading to, among others, exclusion errors and lower benefit levels (Holmes and Uphadya, 2009). This, indeed, applies to all kinds of social protection schemes.

The present system of management of cash transfer by Ministry of Federal Affair and Local Development and distribution through the VDCs has raised a number of issues ranging from inefficiency in delivery of services and mismanagement as well as misappropriation of funds (NPC, 2012). Added by lack of proper record management, some might have received benefits twice at the expense of those who might have been left out of the programs. Such a possibility heightened because of the absence of designated body for coordination, regulation and monitoring (Khanal, 2014). As the same study points out, the cash transfer has been overshadowed by various indicators such as age, single status, ability, caste and region with exclusion of more critical indicators such as poverty and deficiency leading to little improvement in the lives of the poor and weaker groups.

A study by DoE (2010) finds the misuse of scholarship amount due to the lack of fixed and transparent distribution policy and effective mechanism in place in identifying the target group in the schools. Political interference in distributing the scholarship is also identified as one of the major reasons. Another study identifies uncertainties and time lag/delays in disbursement of scholarship as one of the added problems (ERDCN, 2011).

The government data show that number of students getting scholarship has been declining in recent years. In 2010/11, 3.6 million students obtained scholarship which declined to 2.8 million in 2013/14 and 1.7 million up to eight months of FY 2014/15 (MoF, 2015). Although large numbers of girls and Dalit students, district educational offices and schools have found it difficult to cope with the different types of scholarships, identifying the right children, delivering the stipulated scholarship rate at the right time, and ensuring transparency (ADB, 2010). Lack of information about the availability of various kinds of scholarships/incentives and government's inability to provide support to all of the targeted children as announced are some of the pressing problems (Acharya and Luitel, 2006).

$6 \sim$ Nepalese Journal of Insurance and Social Security 
A study by the Department of Education in 8 sample districts found that scholarship distribution is not functioning in an integrated way; and dropout still persists because of child marriage in the case of girls students, domestic work after primary education, support for parents' occupation because of poor economic condition and parental preference in sending their grown up children to India for wage labour (DoE, 2010). Scholarship provided to Dalit students at primary level was found to be relatively more successful than secondary and lower secondary levels. While majority of the parents (75 per cent) told that scholarship amount is inadequate, teachers opined that the scholarship is working as a motivation and encouragement factor to the poor, talented, Dalit, marginalized children, and girls to come to schools regularly and raise interest in the study (DoE, 2010). However, a more extensive study indicates that dropout rate in Dalit students remains still high and performance remains less satisfactory partly due to parents feeling fewer obligations to send their kids to schools as many of them are illiterate and consider that grown-up children have to support their families ${ }^{5}$.

Another study examining the effectiveness of girl's scholarship program in 7 districts finds that the participation of girls in education due to this program has increased over the years resulting into improved Gender Parity Index (GPI), 1.00 for primary and 0.99 for basic education (grade 1-8) in 2009-10 (ERDCN, 2011). In this study, respondents suggest that girl scholarship should be provided to the students from poor families and low human development index. During the study respondents told that the scholarship received ranging from minimum NRs 50 to maximum NRs 500 was highly insufficient. The study also finds uncertainties and time lag/delays in the disbursement of scholarship.

In the areas of health also, access to free health has been reported to be increasing considerably after the launching of the program (Prasai, 2013). As the study indicates, the proportion of clients receiving free care at public health facilities increased from 29 per cent in 2009 to 82 per cent in 2011. Dalits were also recorded to be benefitting from free outpatient services. The frequency and extent of out-of-pocket payments by clients is also reported to be decreasing- particularly among those with serious illnesses but lacking capacity for the expensive treatment. Another study examining the funds flows indicates that fund flows from Ministry of Health and Population to health facilities have improved significantly since 2010. For instance, in mountain, hill and Terai regions 80, 43 and 52 per cents of the Heath Facilities had at least one stock out of the free drug in the last fiscal year (DRC, 2012).

Despite such positive outcomes, more than one third of Nepal's children live below national poverty line and under-five malnutrition stands out 41 per cent at national level

5 Sunam, N. K., Lamsal, H. B. \&Maharjan, S. (nd). An Assessment of the situation of Dalits in Education Policy Gaps, Challenges and Prospects. A Report submitted to Dalit NGO Federation (DNF), Kathmandu, Nepal, Retrieved from http://dnfnepal.org/publication_files/0h9yw8x7 An\%20Assessment $\% 20$ of $\% 20$ the $\% 20$ situation $\% 20$ of $\% 20$ Dalits\%20in\%20Education.pdf. 
(UNICEF, New Era and NPC 2010). The highest rate of malnutrition is observed in five Karnali districts (underweight 42 per cent against 29 per cent national average, stunting 60 per cent against 41 per cent and wasting 13 per cent against 11 per cent) (Rabi, et al. 2015).Among Dalit families, underweight 35 per cent against 29 per cent national average, stunting 47 per cent against 41 per cent national average and wasting 18 per cent against 11 per cent national average (Rabi, et al., 2015). Adhikari et al. (2014) finds that although child grant had some positive impact on access to diversified diet, the value of the Child Grant was too low to buy anything substantial.

Some studies carried out to examine how the old age allowance program is influencing people's views and attitudes states that although old aged people value the recognition of the government by providing allowance, they view that it is too small (KC et al., 2014). Similarly, one of the problems related to the allowance distribution to the disabled is reported to be very poor record keeping. Moreover, because of the quota system not all people with partial disabilities have been able to get allowance from the government (NFDN, 2013). Lack of effective monitoring system is also reported to be encouraging the misuse of funds (NFDN, 2013).One of the serious problems in the areas of social protection is that there are serious lapses in the coordination and monitoring with adverse effect on implementation. This has resulted into less than expected results and outcomes (OPM, 2014).

Although doubling of social assistance has been a right step to cover up basic needs or reduce poverty gap, Nepal at the same time faces serious challenges of extending social security benefits coverage as more than 96 per cent of the total labor force is deprived of social security benefits (CBS, 2009). With very high level of underemployment in general and educated youth underemployment in particular amidst predominance of highly vulnerable informal labor market, social protection is still a major challenge in the context of Nepal (Khanal, 2012). Interestingly, new social security act focuses mainly the formal sector. Apart from continued disproportionate progress in Human Development resulting from, among others, social security gaps, devastating earthquake has increased vulnerabilities. The increased frequency of natural and other forms of disaster and calamities is adding vulnerability of farmers and others.

\section{Methodology}

The paper is prepared on desk review of various studies on social security and social protection in Nepal. In total, 64 papers published from various institutions viz. National Planning Commission, Asian Development Bank, International Labour Organization, Central Bureau of Statistics, Department of Education, DFID, EC etc. and written by the individual authors have been critically reviewed. The reviewed papers were published during 11 years period from 2006 to 2015.The conclusion is drawn and suggestions is offered synthesizing the large amount of information available in reviewed papers.

$8 \sim$ Nepalese Journal of Insurance and Social Security 


\section{Conclusions}

\subsection{Conclusions}

Introduction of old age pension and other assistance programs in the mid1990s has been a historically turning event in the areas of social protection in Nepal. The extension of such programs or introduction of some new ones in the aftermath of 2006 has helped to expand the base of the social protection considerably. Both universal and targeted programs have contributed a lot to reduce the vulnerabilities of the intended beneficiaries. The Dalits, endangered community, school girls, child and people living in the remote areas such as Karnali have been benefitted from numerous social security related programs. The doubling of social assistance is enhancing social protection of those who are in such nets.

Despite positive moves and outcomes, , however, there are not only serious gaps in terms of coverage but also implementation problems which, as in the past, may undermine program effectiveness and better outcomes. Unless options are explored, financial sustainability may come to the forefront more pervasively in the coming days. On the other hand, the benefit levels fixed are yet to take into account the extent of vulnerabilities of most disadvantaged vis a vis others for ensuring more equality. As a consequence, for instance, Dalits who are most disadvantaged and poor have less incentive environment to send their child to the schools. Similarly, as studies point out, lack of easy access amidst discriminatory social or institutional structure is also hampering the intended beneficiaries to get the full benefits of the programs. As an offshoot, there is also outreach problem.

Importantly, programs lack effectiveness compared to increased budget. Scattered programs implemented through different agencies in many instances in an adhoc basis without effective coordinated implementation mechanism has made the outcomes less beneficial and effective from the standpoint of intended beneficiaries.

One interrelated problem is associated with equity dimension. Still the allowances to the poor, women and Dalits could be insufficient to meet their daily needs and fulfil expenditure gaps. Amidst such problems, implementation constraints emanating from poor institutional capacity and funding bottlenecks are constantly obstructing regular and predictable deliveries of cash transfers leading to, among others, exclusion errors and lower benefit levels. For instance, inefficiency in delivery of services, mismanagement and misappropriation of funds remains a major problem in the cash transfer program of Ministry of Federal Affair and Local Development involving VDCs at the local level. The cash transfer has been overshadowed by various indicators such as age, single status, ability, caste and region with exclusion of more critical indicators such as poverty and deficiency. Similarly, time lag or delay in disbursement added by misuse of scholarship has been most common in the absence of fixed and transparent distribution policy and effective mechanism in identifying the target group in the schools. This has adversely 
affected girls and Dalit students. At the same time, in recent year number of students getting scholarship has declined affecting the deprived. Lack of information about the availability of various kinds of scholarships/incentives has also adversely affected the intended beneficiaries to reap the benefits from the different programs. In the health services although free health care and distribution of essential medicine have made some contribution, still malnutrition among children is very high. Such a problem in remote areas such as Karnali and Dalits is very pervasive indicating inadequacy of ongoing efforts. Moreover, majority of disables are prevented from getting the allowance because of the quota system. Lack of proper coordination and effective monitoring system has posed problem of both effective implementation and proper use of funds.

One of the serious challenges in the areas of social security is that still all workers working in the informal economy consisting of more than 96 per cent of the total labor force are outside the purview of social security program. The new Integrated Social Security act has also not covered the workers in the informal sector. Similarly, it encompasses through many ambiguities and overlaps.

Despite extension of programs from one year to another with high propaganda, it is a matter of concern that many of the people entitled to get social security benefits are still deprived. As studies indicate, either due to the ignorance about such a program or in the absence of required documents, a big chunk of entitled population is deprived of getting the benefits of such programs. More worryingly, out of them, most deprived are disabled.

\subsection{Suggestions}

First of all, as per the new constitution, clear cut integrated policy on right based, universal and targeted social protection programs will be needed. The integrated social security act needs amendment following that approach which is still lacking and also there are many ambiguities in its various clauses. In order to effectively tackle exclusion and inequalities and promote sustainable development, coherent design of social protection systems with priority on implementation related institutional dimensions is essential as a key component of broad social and economic development policies and programs. This, among others, requires harmonization and rationalization of fragmented policies and programs depending on their nature to a greater extent. More broadly, social protection system will need designing in a way that it besides enhancing social security could also equally contribute to growth, equality and sustainable development simultaneously.

While doing so, there is a need of extending and ensuring of social security program among those who are still left out with priority on most vulnerable and deprived population with equal priority on disabled. The farmers and disaster victims also may need brining into the orbit of social protection. Above all, due care has to be given to ensure that the discriminatory practices are fully abolished. The geographical bottlenecks and gaps in terms of delivery among districts have to be taken into special consideration. One 
of the interrelated issues to be addressed is the issue of enhancing equity dimension in the program. From the sustainability point of view also this may be desirable. This may require selective approach to ensure that the most vulnerable and disadvantaged get benefits more disproportionately. Although this may be difficult politically in the beginning, more robust but targeted approach may help enhancing the acceptability.

For ensuring social protection systems to provide income security and facilitate employability, a transformative approach will be necessary in which focus should be on creating decent jobs and enhancing employability. In this respect, one important pathway could be a mechanism that facilitates a smooth transition between social assistance and social insurance, with a focus on graduation pathways while strengthening or maintaining strong work incentives. Furthermore, linking non-contributory and contributory-based programs may also help improving the quality of social protection delivery services, reducing dependency syndrome and enhancing the sustainability of programs. Needless to add, financial sustainability is gradually emerging a serious problem and hence needs exploration of better alternatives from longer term perspectives. As an offshoot, this, among others, demands a selective and program by program approach as generalization is neither feasible nor possible.

There is an urgency of improving the efficiency of all programs. This implies an emphasis on reforms that reduce administration costs including leakages of different types and increase the share of the budget reaching the hands of intended beneficiaries. Consolidation of small programs into larger ones using a systems approach may help the improvement in performance considerably. More or extensive use of computer and other communication means and enhanced accountability mechanisms should get priorities.

Along with above initiates from medium to long term perspectives, there is a need of priority on bringing about reforms and changes in specific areas immediately. First, a system of timely availability or release of social security funds for distribution is essential. Second, a new system may need introduction in certain targeted schemes for transferring of funds to the neediest. Third, transparency in payment $\backslash$ distribution to avoid duplication and misuse is a must. Fourth, a system of flow of information on social security related areas by concerned agencies at both central and local level will be necessary. Sixth, as per government announced policy, the service receivers must have bank accounts with priority in their vicinity for easy access. Seventh, timely distribution of assistance on a monthly basis may be essential to ensure that money provided ensures the fulfilment of daily necessities of intended beneficiaries. Eighth, strong coordination among concern bodies and proper monitoring mechanism through new institutional arrangements is a must to ensure program effectiveness and check the misuse of funds.

As the responsibility of distributing social protection funds now comes within the purview of local government, it is necessary that major lapses are addressed by them effectively to ensure that intended beneficiaries are fully advantaged. 
It is instructive to add that in some Latin countries, social security program has been quite effective in reducing both poverty and inequality simultaneously. Under such a program, conditional cash transfer scheme has been used linking with health and education among others in which for a cash transfer to the households, households are required to send their children to the school and also need regular check up of entire family in the health centers in a time bound basis. In some cases, creation of productive asset is also linked. Taking other successful country's experience amidst rising financial liability in an unsustained way due to host of reasons, a new comprehensive approach and strategy may be needed in the Nepalese context as well. 


\section{References}

ADB (2012). Nepal: Updating and Improving the Social Protection Index, Asian Development Bank.

ADB (2010). Overview of Gender Equality and Social Inclusion in Nepal, Asian Development Bank.

ADB(2013). The Social Protection Index: Assessing Results for Asia and the Pacific, Asian Development Bank.

Adhikari, T. P., Thapa, F. B., Tamrakar, S., Magar, P. B., Hagen-Zanker, J., \& Babajanian, B. (2014). How does social protection contribute to social inclusion in Nepal? Evidence from the Child Grant in the Karnali Region. ODI Report, Available at http://www.odi. org/sites/odi.org.uk/files/odi-assets/publications-opinion-files/8921.pdf

Alderman, H. \& Yemtsov, R. (2012). Productive Role of Social Protection, Background Paper for the World Bank 2012-2022 Social Protection and Labour Strategy, Available athttp://siteresources.worldbank.org/SOCIALPROTECTION/Resources/ SP-Discussion-papers/430578-1331508552354/1203.pdf.

Arjona, R., Ladaique, M. \& Pearso, M. (2003). Growth, Inequality and Social Protection, Canadian Public Policy, 29: S119-S139.

Babajanian, B. (2014). The Old Age Allowance and perceptions of the state in Rolpa District, Nepal. Working Paper 25, Secure Livelihoods Research Consortium, United Kingdom. Retrieved from http://www.securelivelihoods.org/publications_ details.aspx?resourceid $=340$

CBS (2009). Report on National Labour Force Survey 2008. Central Bureau of Statistics, National Planning Commission Secretariat, Kathmandu, Nepal.

CBS (2011). Nepal Living Standard Survey Vol.I. Central Bureau of Statistics, National Planning Commission Secretariat, Kathmandu, Nepal.

DFID (2006). Social protection and economic growth in poor countries. A DFID Practice Paper, Available at http://www.gsdrc.org/docs/open/sp16.pdf.

DoA (2014). Proceedings of the National Review Seminar on Food Crisis Response Programme. Department of Agriculture, Retrieved from http://www.iwrm.gov. np/downloadfile/Proceeding\%20Report\%202013-2014\%20First\%20Part_Proc eeding_2IN1_1409120252_1436094208.pdf.

DoE (2010). A Study on Scholarship Management and its Effectiveness in terms of Enrolment and Retention. A Report prepared by Centre for Educational Research and Social Development for Department of Education (DoE), Retrieved from http:// www.doe.gov.np/SoftAdmin/content/A_study_on_A_Study_on_Scholarship_ Management_and_its_Effectiveness_in_terms_of_Enrolment_and_Retention.pdf.

DoHS (2008). National Free Health Service Programme (Implementation Guidelines). (Reprinted 2009). Kathmandu: Department of Health Services. 
DRC (2012). Essential Drug Procurement and Distribution ProgrammeUnder Free Health Services. A report submitted to National Planning Commission by Development Resource Centre (DRC) Kathmandu, Retrieved from http://www.npc.gov.np/web/ new/uploadedFiles/allFiles/essential_drug.pdf.

EC (2010). The 2010 European Report on Development, Social Protection for Inclusive Development. San Domenico di Fiesole, Italy: Robert Schuman Centre for Advanced Studies, European University Institute. Available at http://www.erd-report.eu/ erd/report_2010/documents/volA/reports/ERD_Report-EN.pdf

ERDCN (2011). A Study on Effectiveness of Girls' Scholarship Programme. A Report submitted to Department of Education by Educational Resource and Development Centre Nepal (ERDCN), Kathmandu, Nepal, Retrieved from http://nepalpolicynet. com/images/documents/education/research/'\%20Scholarship\%20Programme. pdf.

ESCAP (2011). The Promise of Protection: Social protection and development in Asia and the Pacific. UNESCAP, ST/ESCAP/2591.

ESCAP (2015).Time for Equality: The Role of Social Protection in reducing Inequalities in Asia and the Pacific. UNESCAP, ST/ESCAP/2735.

Fiszbein, A., Kanbur, R. \& Yemtsov, R. (2013). Social Protection, Poverty and the Post2015 Agenda. Policy Research Working Paper 6469, The World Bank, Retrieved from https://openknowledge.worldbank.org/bitstream/handle/10986/15601/ WPS6469.pdf?sequence $=1$

GC, R. K., \& Shrestha, N., L. (2014). Literacy and Educational Status of Nepalese People. In CBS (2014). Population Monograph Vol. 2 (pp.191-220), Kathmandu: Central Bureau of Statistics.

Holmes, R. \& Barrientos, A. (2009). Child Poverty: A Role for Cash Transfers? West and Central Africa. London: UNICEF and ODI.

Holmes, R. \& Uphadya, S. (2009). The role of cash transfers in post-conflict Nepal (London, Oversees Development Institute), Available at http://www.odi.org/sites/odi.org. uk /files/odi-assets/publications-opinion-files/5743.pdf.

NPC (2015). Social Security Protection in Nepal: Institutional and Capacity Development Final Report.

Joshi, P. L. (2014). Mortality Levels and Patterns in Nepal. Central Bureau of Statistics, Kathmandu

Khanal, D. R. (2012), Social Security/Social Protection in Nepal, International Labour Organization.

Khanal, D. R. (2012), Social Security/Social Protection in Nepal, International Labour Organization.

$14 \sim$ Nepalese Journal of Insurance and Social Security 
Khanal, D. R. (2014). Employment Challenges in Nepal: Trends, Characteristics and Policy Options for Inclusive Growth and Productive Employment, A Report Submitted to ESACAP/SSWA Delhi.

Khanal, S. K. (2014a). Social Protection in Nepal: An Overview, Development Advocate, 2(1): 4-7.

Khanal, S. P. (2014b). Persons with disability and their characteristics in CBS (2014), Population Monograph Vol. 2 (pp.351-376), Kathmandu: Central Bureau of Statistics.

Khatiwada, P. P. (2014). International Migration and Citizenship in Nepal. In CBS(2014), Population Monograph Vol.1 (pp.211- 240), Kathmandu: Central Bureau of Statistics

Kidd, S., W \& Calder, R, (2011). 'Conditional Cash Transfer Programmes: their relevance for Nepal'. Discussion paper. DFID Nepal.

Koehler, G. (2011). Social Protection and Socioeconomic security in Nepal, CSP Working Paper No. 1.

Koehler, G. (2014). Social Protection in Nepal: Challenges and Ideas, Development Advocate, 2(1): 8-13.

MoHP (2002). Nepal Demographic and Health Survey 2001. Ministry of Health and Population, Government of Nepal, Kathmandu.

MoHP (2007). Nepal Demographic and Health Survey 2006. Ministry of Health and Population, Government of Nepal, Kathmandu.

MoHP (2012). Nepal Demographic and Health Survey 2011. Ministry of Health and Population, Government of Nepal, Kathmandu.

MoF (2014), Budget Statement for 2014/15, Ministry of Finance, Government of Nepal.

MoF (2015). Economic Survey Fiscal Year 2014/15, Ministry of Finance, Government of Nepal.

MoF (2015a). Budget Statement for 2014/15, Ministry of Finance, Government of Nepal.

NFDN (2013). Budget Mapping of the Disability Sector in Nepal. National Federation of the Disabled Nepal (NFDN), Kathmandu, Retrieved from http://nidanepal.org. np/wp-content/uploads/2014/09/Budget-Mapping-of-Disability-Sectors-inNepal-2012.pdf

NPC (2012a) Assessment of Social Security Allowance Programme in Nepal, National Planning Commission, Kathmandu.

NPC (2012b). Assessment of Karnali Employment Programme. National Planning Commission, Kathmandu.

OPM (2014). Social protection through public works in Nepal: Improving the Karnali Employment Programme. Briefing Note, Oxford Policy Management, Retrieved 
from http://www.opml.co.uk/sites/default/files/Briefing_Note_KEPTA_Lessons_ learned_final.pdf.

Pradhan, A. (2014). Maternal Mortality. In CBS(2014), Population Monograph Vol. 1 (pp.141-159), Central Bureau of Statistics, Kathmandu

Prasai, D. P. (2013). Review of Studies on Nepal's National Free Health Care Programme. A Report submitted to Department of Health, Ministry of Health and Population, Retrieved from http://www.nhssp.org.np/gesi/Free\%20health\%20 services $\% 20$ (QA)\% 202013_12_02.pdf.

Rabi, A., Koehler, G., Okubo, T. \& Dahal, T. (2015). Strategies and options for scaling up and enhancing the child grant nationally in Nepal. Nepal Working Paper Series, WP/2015/002. Retrieved from http://www.un.org/esa/socdev/csocd/2016/ Nepalchildgrant-GK.pdf.

Sen, A. (1992). Inequality Re-examined. Oxford: Clarendon.

Sen, A. (1999). Development as Freedom. Oxford: Oxford University Press.

Shakya, K. (2014). Changing Gender Status: Achievements and Challenges. In CBS (2014), Population Monograph Vol. 2 (pp.221-271), Central Bureau of Statistics, Kathmandu.

Singh, M. L. (2014). Aspects of Aging. In CBS (2014), Population Monograph Vol. 2 (pp.73110), Central Bureau of Statistics, Kathmandu.

Sunam, N. K., Lamsal, H. B. \& Maharjan, S. (nd). An Assessment of the situation of Dalits in Education Policy Gaps, Challenges and Prospects. A Report submitted to Dalit NGO Federation (DNF), Kathmandu, Nepal, Retrieved from http://dnfnepal.org/ publication_files/0h9yw8x7An\%20Assessment\%20of\%20the $\% 20$ situation $\% 20$ of\%20Dalits\%20in\%20Education.pdf.

Suwal, B. R. (2014). Internal Migration in Nepal. In CBS(2014), Population Monograph Vol. 1 (pp.241-283), Central Bureau of Statistics, Kathmandu.

Suwal, R. \& Dahal, M.P. (2014). Economically Active Population: Dimensions and Dynamics. In CBS(2014), Population Monograph Vol. 3 (pp.1-40), Central Bureau of Statistics, Kathmandu.

The World Bank. (2013). Nepal Human Development Note: Access, Equity, and Quality in the education, Health and Social Protection Sectors. Washington: Human Development Unit, South Asia Region.

UNDP (2013). Social Protection, Growth and Employment Evidence from India, Kenya, Malawi, Mexico and Tajikistan. Retrieved from http://www.undp.org/content/ $\mathrm{dam} /$ undp/library/Poverty\%20Reduction/Inclusive\%20 development/ Social\%20protection,\%20growth\%20and\%20employment/Draft8_SPG\&E_web. pdf

$16 \sim$ Nepalese Journal of Insurance and Social Security 
UNDP (2014). Human Development Report 2014. Retrieved from http://hdr.undp.org/ en/content/table-2-human-development-index-trends-1980-2013.

UNDP (2015). Human Development Report 2015. United Nations Development Programme, Retrieved from http://hdr.undp.org/sites/default/files/2015_ human_development_report_1.pdf

United Nations Children's Fund, New Era, and National Planning Commission (2010). Child Poverty and Disparities Nepal, UNICEF, Kathmandu, Nepal.

Upreti, B. R., KC, S., Mallett, R. \& Babajanian, B.(2012). Livelihoods, Basic Services and Social Protection in Nepal, Working Paper No. 7, Secure Livelihoods Research Consortium.

S. and Luitel, B. C. (2006). The functioning and effectiveness of scholarship and incentive schemes in Nepal. UNESCO, Kathmandu. Retrieved from http://unesdoc.unesco. org/images/0014/001460/146085e.pdf.

Townsend, P. (ed.) (2009) Building Decent Societies: Rethinking the Role of Social Securityin Development. Basingstoke: Palgrave Macmillan/ILO.

http://www.ilo.org/wcmsp5/groups/public/---asia/---ro-bangkok/---ilo- ILO (2010). World Social Security Report 2010/11: Providing Coverage in Times of Crisis and Beyond. Geneva: ILO.

UNDP (2013). Social Protection, Growth and Employment Evidence from India, Kenya, Malawi, Mexico and Tajikistan. Retrieved from http://www.undp.org/content/ $\mathrm{dam} / \mathrm{undp} /$ library/Poverty\%20Reduction/Inclusive\%20development/ Social\%20protection,\%20growth\%20and\%20employment/Draft8_SPG\&E_web. pdf kathmandu/documents/meetingdocument/wcms_417359.pdf

Upreti, B. R., KC, S., Mallett, R. \& Babajanian, B.(2012). Livelihoods, Basic Services and Social Protection in Nepal, Working Paper No. 7, Secure Livelihoods Research Consortium. 